\title{
Podocarpus acuminatus (Podocarpaceae), a New Species from South America
}

\author{
David J. deLaubenfels
}

Department of Geography, Syracuse University, Syracuse, New York 13244-1160, U.S.A.

Abstract. A new species, Podocarpus acuminatus, from southern Venezuela and nearby Brazil is described.

A new species of Podocarpus was recognized in material recently collected in South America.

Podocarpus acuminatus de Laubenfels, sp. nov.

TYPE: Brazil. Amazonas: Serra da Neblina. Farney 870 (holotype, MO).

Folia linearia vel ovata, ca. 3-4 cm longa, $8 \mathrm{~mm}$ lata, acuminata, plus minusve revoluta; juvenilia $10 \mathrm{~cm} \times 13$ $\mathrm{mm}$. Gemma globularis; squamae cuspidatae, 4-6 $\mathrm{mm}$ longae. Tegmina carnosa ovata seminorum crista prominenti, l mm longa, praedita; receptaculum 3 bracteis obtectum.

Small tree 4-5 m tall. Leaves linear to ovate, ca. 3-4 cm long $\times 8 \mathrm{~mm}$ wide, acuminate, slightly revolute; juvenile leaves to $10 \mathrm{~cm} \times 13 \mathrm{~mm}$. Foliage buds globular; bud scales erect, cuspidate, 4-6 mm long. Fleshy covering of the seed with a prominent apical crest $1 \mathrm{~mm}$ long; receptacle with at least three bracts: with one seed a third, smaller bract occurs below the usual sterile bract, with two seeds one or more smaller bracts occur between the two fertile bracts. Pollen structures unknown.

Distribution. Grows as an exposed tree in cloud forests and among rocks, at 1,900-2,400 m.
Acuminate leaves are uncommon in Podocarpus, and there are no examples among closely related species, all of which occur in South America, with acuminate leaves anywhere near the size of those of $P$. acuminatus. Among other Venezuelan species of Podocarpus (see deLaubenfels, 1982), P. magnifolius is the only closely related one with acuminate leaves, and it is noted for its large leaves more than $18 \mathrm{~mm}$ wide. Similar-sized leaves occur in P. buchholzii and P. brasiliensis, where the acute to blunt leaves show no signs of an acuminate apex (deLaubenfels, 1982). The extra sterile bracts on the fertile structures are unusual and have not previously been observed on any South American species. The prominent crest helps to differentiate $P$. acuminatus from the other South American species with similar-sized leaves. Short, erect, cuspidate bud scales are also distinctive.

Paratypes. Venezuela. amazonas: Sierra de la Neblina, Nee 30743 (MO). Bolivar: Chimantá, SW Amurítepui, Huber 11408 (MO).

\section{Literature Cited}

Laubenfels, D. J. de. 1982. Podocarpaceae. In: Flora de Venezuela 11(2): 7-4l. 


\section{$2 \mathrm{BHL}$ Biodiversity Heritage Library}

Delaubenfels, David J. 1992. "Podocarpus acuminatus (Podocarpaceae), a New Species from South America." Novon a journal of botanical nomenclature from the Missouri Botanical Garden 2, 329-329.

https://doi.org/10.2307/3391488.

View This Item Online: https://www.biodiversitylibrary.org/item/14662

DOI: https://doi.org/10.2307/3391488

Permalink: https://www.biodiversitylibrary.org/partpdf/122222

\section{Holding Institution}

Missouri Botanical Garden, Peter H. Raven Library

\section{Sponsored by}

Missouri Botanical Garden

\section{Copyright \& Reuse}

Copyright Status: In copyright. Digitized with the permission of the rights holder.

License: http://creativecommons.org/licenses/by-nc-sa/3.0/

Rights: https://biodiversitylibrary.org/permissions

This document was created from content at the Biodiversity Heritage Library, the world's largest open access digital library for biodiversity literature and archives. Visit BHL at https://www.biodiversitylibrary.org. 